\title{
Editorial: School Leadership during the Disruptive Time of COVID-19
}

\author{
Phumlani Myende \\ ORCID iD: https://orcid.org/0000-0002-4592-0228
}

\section{Jan Heystek \\ ORCID iD: https://orcid.org/0000-0001-7695-5047}

\section{About the Special Issue}

This special edition of Alternation provides insight in school leadership during the initial six months of the COVID-19 pandemic, from March 2020 to October 2020. This period ended in October 2020, since that was the due date for submission of articles. Therefore, the special edition reflects the initial reactions of school leaders and their followers during the initial period of the crisis brought on by the COVID-19 pandemic. This pandemic, which is still with us, created challenges which leaders have not experienced before and so, this edition is mostly about the leadership challenges and initial initiatives adopted during this complex time.

The articles range from empirical work on how leaders experienced the pandemic, and exercised leadership during these six months, which also included the initial lockdown of three months, followed by the uncertainties of opening or closing schools again. It also includes conceptual and philosophical approaches and perspectives on school leadership during the specific time of this world crisis, that have impacted education worldwide in a very wide variety of ways.

The issue also attempts to provide different perspectives, ranging from suggestions on how to lead during a crisis, to challenges for leadership development in this context, and the impacts of a crises of this magnitude on orthodoxies of leadership, and leadership discourse, as we move forward into an uncertain future. The concepts of the 'new norm' and returning to the 'old norm' of school leadership have also been challenged. By the time of public- 
cation, it is already more than a year after the initial lockdown of society and schools in particular, in South Africa, and therefore, the general situation has changed. Even so, the issue captures a special moment in time, on school leadership, and may be followed with research and critical reflections on how school leadership has progressed from the time of the initial six months.

Although there was a decision from the National Department of Basic Education during August 2021, that learners must all return to schools because the last part of the academic year was to be salvaged, it was not practically possible for a large number of schools, since they did not have the facilities to comply with the COVID-19 rules and regulations with regard to physical space and sanitation (in many times due to lack of water supply). So, the socioeconomic challenges for education as we have experienced it during the 'normal' pre-COVID period, continues for the majority of learners in South Africa, compounded by the effects of having to teach and learn in COVID conditions. As such, it has also raised the spectre of yet another 'lost generation' of pupils since the end of the pandemic is not in sight yet, and the education progress for most learners is significantly impeded.

While the disruptive time of COVID-19 has had multiple effects on different educational stakeholders' work, we have assumed, for this special issue, that school leaders are the ones who feel the pressure more than anyone else, given the multiple accountabilities (Myende et al. 2018) they encounter and have to creatively deal with in education every day. So, as existing research demonstrates, there are high expectations for education to make a transformative contribution to socio-economic growth and development in developing economies (see Economic Policy South Africa, with references; and Grant 2017 for instance). Yet, with the advent of the multiple disruptive effects and impacts of the COVID-19 pandemic, this has put school leaders under even more pressure to provide leadership in challenging times. They are expected to produce good results amidst all the existing challenges such as poverty, poor infrastructure, and lack of quality human resources. COVID-19 has now compounded these even more.

Therefore, given our pre-COVID-19 challenges, that made school leadership a complex task, as it is, through this special issue of Alternation, we also wish to foreground a sample of the complexities and responsive leadership from South Africa, and elsewhere. In this regard the issue digs deeper into the complexities of leading and governing schools, also bringing to the fore how these have been exacerbated during the time of the crisis that 
was brought on by COVID-19.

In the next section we briefly explore aspects of school leadership as these have arisen during this period of crisis.

\section{The Disrupted School Leadership Crisis}

During times of crisis, school leaders 'cannot emulate leadership practices they witnessed or enjoyed in a period of stability, continuity and relative calm. Leading in disruptive times means being able to navigate a different course, to create new pathways through the disruption' (Harris \& Jones 2020: 246).

While school leaders and governors may be aware of the complexities and disruptions that times of crisis present to their work, there is now a global consensus that leadership during crisis is a daunting task requiring unprecedented ideas and actions. Harris and Jones (2020: 246) argue that crisis leads to the emergence of a new leadership order which is characterised by no 'leadership standards, no preparation or development programmes, no inspection and leadership framework, no key performance indicators and no benchmarks'. The disruption in school leadership came about through the effects of COVID-19 on education and more especially to school leadership, which registered the entry into leadership mode described above. It did not only interfere and interrupt leadership processes in our specific developing world contexts, but also diverted attention away from primary concerns related to education for socioeconomic growth and development, to emergency measures for the purposes of saving lives. It was in the wake of the World Health Organisation (WHO) declaring the global public health emergency, and the call for international measures to respond to the pandemic (McKibbin \& Fernando 2020; Poudel et al. 2020; Viner et al. 2020).

Although pandemics have been experienced in the past - such as the Spanish flu (1918 - 1919); the Asian flu (1957 - 1958); the Hong Kong flu (1968 - 1970); and HIV\&AIDS since around 1981 to the present (Maital \& Barzani 2020) - for the first time in history, the majority of countries, whether affluent or destitute, had to put systems in place to respond to the health, educational, economic and political challenges caused by COVID-19 (Poudel et al. 2020). Globally, the different societal sectors experienced severe pressure to find the best ways to mitigate the impact of the pandemic, even though most often, these were experimental with some countries opting 
for intervention strategies that caused contradictions in respect of the demands of protecting the health of the population and saving lives, on the one hand, and salvaging the national educational and economic systems (Kochańczyk \& Lipniack 2021). One of the sectors that was hit most severely, causing extreme disruption, by COVID-19 globally, was education. At the time WHO declared COVID-19 as a global pandemic, 862 million children and young people (roughly half of the school going population), from 107 countries that had embarked on school closure, were directly affected in their school attendance and educational progress (Viner et al. 2020).

On the $26^{\text {th }}$ of March 2020, South Africa, joined her sister countries when the President of the Republic announced schools' closure (Mhlanga \& Moloi 2020). While school closures had been adopted by different countries, education systems of developing countries like South Africa, suffered more disruption and pressure to continue the school year, despite the disruptions, compared to their developed counterparts (Tadesse \& Muluye 2020). While many schools and higher education institutions in affluent countries transitioned from face-to-face teaching and learning, to emergency online teaching and learning (EOTL) (Myende \& Ndlovu 2020) with less hassles, developing countries, due to their lack of access to digital technologies and other relevant software resources (Di Pietro et al. 2020; Ramij \& Sultana 2020) experienced great difficulties.

Lack of digital technologies and resources for promoting EOTL, meant governments and even more crucially the education leadership fraternity, in developing countries like South Africa, had to be 'on their toes' in trying to develop new systems for ensuring that teaching and learning took place and the effects of the pandemic were mitigated to some degree. Unlike affluent countries, and especially those that have been making certain advances in digital technology and remote online teaching and learning for more than a decade, the impoverished countries had a handful of schools that could transition to EOTL on short notice. For many schools, the crisis, or the emergency, was not only to find accessible digital technologies, to transition to digital wi-fi and related systems on short notice and to develop content that pupils could follow on cell phones for instance. In developing world countries, we also had the added burden of excessive data payments in poverty-stricken households, and that due to the novelty of online or digital learning, it was extremely challenging to get education systems and pupils, to start to learn via remote systems of teaching, for some months. Added to 
this, was the challenges learners experienced with regards to staying focused on learning, and not to succumb to the distress of people in poor households contracting COVID-19, being hospitalised or passing on. Saving lives was of paramount importance and education came second.

All schools had to be innovative and take initiatives to mitigate the impacts of COVID-19 on health and learning. New plans for complying with COVID-19 rules meant that those who lead schools, needed to be innovative and shift to crisis leadership or what Francisco et al. (2020) call the 'new normal leadership'. As a result, school leaders, managers and governors encountered insurmountable pressures as they were required to find solutions to unprecedented complexities. School leaders, managers and governors were not only faced with the task of ensuring that teaching and learning occurs, that utmost attempts are made to complete the academic year, and were also required to ensure that teachers, learners and other non-teaching staff are supported in terms of their psychosocial wellbeing (Metcalfe \& Perez 2020). So, these complexities called for innovative critical tasks with the aim of optimally continuing processes of teaching and learning that would lead to learner success and the saving of the academic year for most.

Based on the above complex challenges, mostly encountered in developing countries, this special issue of Alternation is aimed at exploring the challenges, dimensions, conceptual frameworks, theories, contexts, and best practices as well as the nature of meaningful leadership, management and governance of schools in the context of the crisis brought on by COVID19 in developing countries and their socioeconomies. Against this aim, and amongst some flagged, that need to be explored further, the articles in this special issue address the following critical questions:

- What theory and practice frameworks can school leadership, management and governance employ to guide best practice during this time of the unprecedented and disruptive challenges emanating from COVID-19?

- What school processes and procedures could school leadership, management and governance deploy to foster accountability, integrity and responsiveness among staff and pupils during times of crisis like these? 
- What can we learn from other continental and global education systems with regard to constructive and creative responsiveness by school leaderships in terms of guiding staff, pupils, and the parent cohorts, in respect of the education disruptions accompanied COVID-19.

- Which styles of leadership could be deployed to enhance innovative cultures of teaching and learning at school levels and in the education system in general, that are enabling to all involved in school leadership, management and governance, during this time of COVID-19?

- How do varied urban and rural school contexts determine how the nature and quality of school leaderships are conceived, initiatives engineered, and measures taken and applied during this period of COVID-19?

- Which forms of decentralised education leadership and management structures, as well as forms of the devolution of power, could be helpful and enable, or inhibit or frustrate and counteract, quality and best practices in benchmarked school leadership, management and governance responses to COVID-19 at school levels?

\section{Developing Economies, Provision of Education and COVID-19}

We have indicated earlier that concerns of poor infrastructure, poverty and lack of quality human resources have been some of the sectoral educational challenges in many developing economies even before COVID-19. Beyond the above challenges, developing economies are further characterised by the continuing digital divide which can be defined as the inequality in how digital resources are distributed (Myende \& Satimburwa 2020; Khlaif et al. 2021) amongst members of these communities. In digitally divided societies, some communities who happen to be the minority have full access to digital educational resources that enable children in such communities to have access to these resources which not only ensures the optimum completion of the educational curriculum, but also results in the attainment of quality education, in spite of the discontinuing of face-to-face teaching and learning. 
Contrary to the above, a digitally divided community has the majority members who do not have access to digital technologies and in this case of lockdown, where face-to-face teaching and learning is prohibited, these members of the community remained without access to education. This exacerbates already existing constrained socio-economic conditions of learning and teaching. This is one feature of the state of education in developing economies which was there before COVID-19. COVID-19 required schools to close (Viner et al. 2020) and those minority communities who have already had access to digital technology or were on the way to transition to fully-fledged blended teaching and learning, could immediately take action, upscale their systems, and migrate to full-scale online remote teaching and learning. This, in Myende and Ndlovu's (2020) view exacerbates the already existing unequal provision of education. One of the key roles of school leaders is to see to it that quality education is provided to all learners and there is no doubt that the crisis of COVID-19 affected this role. It was therefore part of our interest to understand what it means to lead and govern schools in a context experiencing this double dilemma of COVID-19 and the complexities it brought on, especially in a developing economy, such as South Africa's.

When the majority of schools closed, most did not do much, but just waited for the pandemic to pass, and for schools to reopen again. When schools reopened, a phased-in approach to schools' opening was used, with some schools lagging behind others. South Africa is one of the countries that used this approach, with the resultant kick-on effects. Due to limited classrooms, some children only came to school for two days per week. Then, within the phased-in approach, some learners were expected to learn at home while it was other learners' turn to be at school.

Moreover, in addition to being digitally disconnected (Park 2017), children in most developing economies also continue to find themselves in homes that do not have space and resources for learning at home. For some children being away from school also meant being fully involved in house chores (Myende \& Ndlovu 2020). There is no doubt that a very large portion of our school-going population continues to be deprived of full access to education, a challenge each school leader or governor needs to think about at all times, and with which many struggle. At the heart of leadership is the question of not only how to lead teaching and learning in our regular socioeconomic contextual challenges, but also how to lead and provide effective 
guidance in this period of the phased-in approach, so that learners are still able to receive education of a high quality and standard despite scarce resources and adverse learning conditions at home.

It is through this special issue that again, we wanted to ponder a selection of these challenges, and foreground the complexities but also workable initiatives in the leadership of teaching and learning, in a context that is not conducive for learning at home, while learners have to engage study from home despite socioeconomic difficulties.

Against the challenges highlighted above, as it stands at this point, we may also note that there is limited research on school leadership and governance during the crisis of COVID-19 focusing on developing economies - hence, our Call for Meaningful, Innovative Leadership, Governance and Management of Schools in Developing Economies during the Disruptive time of COVID-19.

Finally, as required, we provide the brief abstracts of the articles that follow, to give the reader a bird's eye view of the whole issue, below. And, even though there are many thematisations that overlap and are integrated across the articles, we have decided to structure them around some key themes. We hope these might be helpful for further research and informed academic reflection.

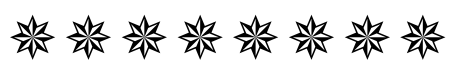

\section{Conceptual}

Inbanathan Naicker and Vitallis Chikoko share the experience of academics about 'School Leadership Theory and Practice in Times of COVID-19: Our Learnings from a National Webinar'. They explored the possibility with academics and practitioners, as to whether school leaders could continue with the leadership practices during lockdown, which they used before the COVID-19 situation. For them, leadership implies - amongst other key issues - that leaders be proactive. That is what has been expected from the principals as leaders in many of the schools as lockdown ensues. This was not always possible, since the principals lacked the training, knowledge and experience and also did not have sufficient information to be proactive in the decision-making required under these circumstances. Although a people orientation is normally associated with effective leader- 
ship, it seems as if an ethics of care became more important during the virus phenomenon and that leaders had to pay more attention to this. The principals were therefore challenged physically but also psychologically since the demand was for education to continue and learners and teachers to teach while the psychological challenge was to take care of the stress and anxieties of pupils and staff members, in addition to the deployment of measures that prevented the virus from spreading. The ethics of care, twinned with the challenges for the continuation of education, therefore, became a complex conundrum for the principals - which also challenged the kind of leadership in which they were schooled and which they practiced. The authors refer to courageous leadership as well as resilient leadership, which are needed during a crisis in the schooling system, as brought on by COVID-19. Although these leadership approaches may be new for some, the authors emphasise that these must be promoted and made the preferred approaches, so as to enable schools to continue to function optimally. They also bring to the fore the challenges the learners from low socio-economic contexts experience, and that principals must make provision for the most vulnerable learners, which is also emphasised by Mestry and others below, with regard to the feeding programme and the training and development of staff members, so as to continue teaching even during lockdown and even the closure of schools. In addition, it was specifically also during the first few months after the schools re-opened in June 2020 again, that the slogan of 'sanitation before education' was at the forefront of the concerns of leadership. This posed huge challenges for principals, so as to get children and teachers at the school and not too close schools, and therefore the requirements of sanitation and for social distancing, which became even more important than actual teaching.

Sadi Mokhaneli Seyama expressed the opinion in the article 'Possibilities of Functional Stupidity in Leading Schools during the COVID-19 Pandemic: A Case for Pandemic Leadership', that leadership during a crisis can cause more harm than good since leaders might follow 'stupid' rather than informed strategies, and so risk the health and safety of staff and pupils. This also raises question marks about the reliability of leaders. The COVID-19 context raises issues that leaders find difficult to navigate through, as expected, with a clear vision and direction. Since followers are used to follow the leaders, the COVID-19 situation may cause 'functional 
stupidity', where some 'stupid' followers follow leaders blindly, or even reject sensible leadership. Since all have to lead their schools and navigate through the crisis without clear guidance, the educational leaders from the national ministry, to the principals at the schools, are also caught in the duality of emphasising the continuation of schooling with all learners at school and the demand to protect lives and therefore not bring learners simultaneously together to the schools. This challenge further confuses the followers - from the teachers to the parents - and has the consequence that there is also a divide in the debate around these two groupings. The author indicates that critical leadership studies emphasise that in such circumstances, leaders are vulnerable and specifically during the COVID-19 pandemic. So, the pre-COVID-19 leadership context that required a pragmatic approach, may not be the appropriate approach in this complex context. So, the more complex side of leadership and ineffective leadership have been highlighted during the COVID-19 pandemic - i.e. where leaders are not able or less able, to secure education for the learners through pragmatic choices and means. As already stated, the context of low socio-economic circumstances also has a significant influence on the quality of leadership. So, it appears that the leadership at some schools could have been better, if a more critical leadership approach has been followed, rather than just the pragmatic day-to-day leadership practices of the past.

\section{Conceptual and Theoretical}

Renuka Ramroop and Rachael Jesika Singh challenge the current system to rethink its functioning in the new dispensation of uncertainty linked to COVID-19, in their article, 'COVID-19 Forces a System Change Rethinking Schooling towards a 'Learning Society' Framework'. They explore the essence of what learning is, who must be learning, and who is responsible for learning. This becomes relevant and important, in respect of the taken for granted processes that challenges related to COVID-19 pose. The challenges of the reality for learners to do home-schooling was stronger especially during the initial stages of lockdown. Following this phase, the matter of 'comorbidities' - that included illnesses such as diabetes 1 and 2, lung and heart problems, HIV/ Aids - became the buzzword. Comorbidities allowed children and teachers to work from home which not only created challenges for the school leaders to manage their optimum functioning, but also challenged the concept of learning, and who is responsible for learning. 
The ingrained system of instruction or teaching as a prerequisite for learning are challenged under the umbrella of the governmental, and rationality of the education system presented by the governments, as solutions for improved education. It is specifically the divide between privileged and underprivileged schools in the South African education system which necessitates the rethinking of learning, since schools in the underprivileged contexts are not able to continue their learning and therefore are further disadvantaged in the system which is expected to provide quality education for all. The option of self-learning in a conducive home environment (which may be equated with self-directed learning) also became an important issue of contention, as also already indicated in the introduction above. Families in lower socioeconomic contexts have challenges which may be a stumbling block or even totally prevent self-directed learning, with poverty, single parent houses, the influence of HIV/Aids, the lack of funds, which link to limited access to news and books and journals and educational information, all aggravated by the COVID-19 context. These families have these burdens where learners need to but are unable to engage in self-learning, and s are deprived of the formal but also informal learning from the parents, and exposure to a wider world outside the small house or community.

Thamsanqa Thulani Bhengu focused his perspectives on governance. The governance of schools is just as important as leadership, since those who govern the schooling system, have important roles with regard to the provision of facilities and support to principals and teachers. In the article titled 'Can Decentralisation of Structures and Devolution of Gover-nance Power Enable an Effective Response to COVID-19 Disruptions? Lessons from the South African Education System', Bhengu then engages the decentralisation of the system and the importance of the power in decision-making in the relationship between the professional management of the schools by the principal and the governance from the governing body where the parents are the majority. Bhengu emphasises that the diversity in the quality of education in schools, based on the historic past is still prevailing and this is an important challenge for the schools in the lower socioeconomic strata of society. The indication is that very little has changed with regard to the divisioning of schools more than 20 years after the end of apartheid. Schools are still divided into schools with abundant and those with limited facilities - which is the majority of the schools. The emphasis 
on decentralisation and local decision-making is therefore possibly an option for the improvement of education in such contexts, since the local school may be able to make faster and better decisions for the local context. This conceptual paper indicates that although the decisions are decentralised with regard to the governance though, the strong centralisation from the National Department of Basic Education is continuing to overshadow the local decisions. Principals and governing bodies have to act according to the decisions made at national levels, for example with regard to the closing and opening of schools. The unpredictability and uncertainty of the potential devolution of power, is therefore a challenge at the different levels in the education system with regard to the power that emanate from the national level and its impact on to the local levels in a decentralised system.

\section{Contextual}

The article by Dorcas Ettang emphasises the challenges faced by migration and migrant learners in the school system. This article does not only focus on South Africa, because migration is a world phenomenon. The article, 'Migrant Learners in a COVID-19 Context: Exploring Strategies for School Leadership and Management shows how the virus situation emphasise the pronounced plight of migrant learners. From the normal challenges which they experience, such as language barriers and not being at school continuously because of their travels, and changes in their movements between cities and countries, the COVID-19 situation exacerbated these experiences. Lockdowns prevent them to move to join families or relatives and therefore families have to stay longer times apart. They also lack the electronic and internet access and facilities, possibly to a larger extent than parents and learners who are permanently located within their own houses and within their own well-established communities. This required in contexts of already challenging circumstances, that principals are encouraged to practice a culture of care and sensitivity towards these learners and to be cognisant and supportive of the bigger diversity in their schools, especially those with large contingents of immigrant learners. In addition, the language barrier is also more specific to primary schools, where language becomes a challenge for communication between school going children and schools and parents, who are not fluent in the local language(s) and/ or English as the medium of communication, which is most often the lingua franca for most schools. 


\section{Policy}

The next article focuses on adaptive leadership and argues that leadership need to adapt to context and situation to enable schools to continue with quality education. Edwin Darrell de Klerk and June Monica Palmer indicate in their article, 'Policy Analysis for School Leaders' Development during COVID-19: An Adaptive Leadership Practice Framework' that the policy on the standards for South African principalship may be able to adapt to the COVID-19 situation, while not limiting the training and experience of principals. The policy expects principals to transform and change the schools. Although this was not conceptualised with the context of COVID-19 in mind, the interpretation and adaptation of leadership for the virus, based on the policy, provided the principals with the potential to be still effective and functional. The standards document emphasise shared leadership which became more important during the virus situation, where principals and communities and the role players in the school - specifically the teachers - need to share responsibility and leadership to be able to survive the uncertainty and challenges. This shared leadership contributes to the empowerment and development of more role players which may be able to assist and so be to the advantage of the schools and communities in the future.

\section{Lucy A. Wakiaga's article, 'Lessons from COVID-19 in Disaster Pre-} paredness: An Examination of Kenya's Education Sector's Disaster Response and Management Framework', contributes another international perspective to the majority of the South African perspectives in this special edition. The context of Kenya is similar to South Africa as both countries are developing African countries. Her approach indicates the potential of such an education system to absorb abnormal and significant changes, by bouncing back following certain challenges, which also need to take into consideration that they will need to learn resistance to the detrimental changes which is required after impacts such as the COVID-19 pandemic. Wakiaga uses Wenger's (2017) modified PPRR Framework to explain the reaction of the Kenyan education system with regard to the COVID-19 context. She indicates that a crisis like this, cannot easily be understood and must therefore not be managed as a linear system - as proposed by Wenger. It is much more complex and therefore needs at least adjustments of the linear process. Although contextual solutions may be appropriate, it also has the 
challenge that it may not include all the significant information on the related complexities, which is needed if only the local context is taken into consideration.

\section{Empirical Studies}

Wei Zhang, Michelle Striepe and Christine Cunningham provide information about School Leadership during the COVID-19 Crisis: A Preliminary Case Study from China', as the country from which the COVID-19 pandemic originated. The research in the case study school indicates that the leaders focused on supporting student learning as well as the needs of student well-being and parental concerns, with the support of the teaching staff. The school closure occurred at the end of January 2020, a few months before it happened in South Africa, but the principals experienced the same emotions of fear and uncertainty as was the case in South Africa. The closure of the schools was just before the start of the new academic year and the demand was to transition and continue with online teaching. The similarity with South Africa continues, as the instructions from the Department of Education continues to change and disrupt the planning at the school level which created more frustration and uncertainty among teachers, learners and parents. The principal used a hands-on approach with a new teaching design. She was not certain if it was going to work and therefore joined chat groups and observed teacher lessons online, so that she could act immediately if she saw something which may not be according to the quality in the planning. The principal labelled the period from May to September the 'moving past the crisis' period. This is interesting, since it is how leaders experience a crisis and when and how they are moving past the initial crisis into a new situation, which may become a new norm. Although the medical crisis has not been averted, the crisis at the school level seems to be well managed and therefore the school moved past the initial crisis with a new teaching methodology and most teachers and learners were able to adapt to an acceptable level. This primary school was able to move swiftly through the initial crisis phase and even the decisions from the principal based on little evidence or experience, moved the school forward with strong collaboration from teachers and parents.

Emile Bosch, Jan Heystek, Marvin Madisa, Victor Mogonediwa and Stormburg Vuyile Tiwani provide a perspective from different provinces in the country as well as from schools in different socio-economic contexts. 
The 'Principals' Narratives about Leading Schools during the COVID19 Crisis in South Africa', emphasises the differences between schools in low socio-economic contexts, and schools in middle-class and high socioeconomic contexts. The principal in the high socio-economic context had the advantage of good communication with the children and their parents as well as different forms of electronic communication to support the learners during the first closure of the school from March to June 2020. Schools in low socioeconomic context did not have these financial abilities and the parents in general do not have access to internet and/ or electricity and therefore it is difficult to even impossible, to continue with any education during the school change. This emphasise again the diversity between the schools in South Africa. The learners in the majority of the schools in South Africa therefore lost on education for a long time which just broadens the divide between quality education and also substantial education in just the basic education levels. Equal education opportunities are therefore emphasised, which is an important social justice issue for the country. The significant uncertainty and lack of information during the initial phase of the closure of schools from March 2020, contributed to the challenges which principals had to manage. They were not certain when the schools were going to open again, and did not have rules which need to be followed, for example with regard to sanitation and personal equipment, which was supposed to be received from the Department of Education. In some provinces this was a major challenge and delayed the opening of the schools.

The article by Aruna Ankiah-Gangadeen and Pascal Nadal is, 'An Exploration of School Leadership in Times of Crisis: Implementing Online Teaching during COVID-19'. It focuses on the use of online teach-ing in Mauritius at the beginning of the COVID-19 pandemic. As part of the developing world this is a big challenge and this is a good example of how schools had to adapt to ensure that quality education is still provided for all equally. A case study was carried out, to obtain insights into the leadership styles rectors adopted during confinement, to implement policy decisions, while navigating between key stakeholders, e.g. the Ministry, teachers, parents and learners. It was important in the implementation of the online teaching that there was a good relationship and balance between task and person orientation. A democratic approach and considering the learners also as important, account for the success of this implementation. The contextual factors are 
important, and these challenge the leaders in an uncertain and new context.

Pierre du Plessis, in his article, 'COVID-19: Leading in Disruptive Times - Challenges for School Leaders', assert that it was a chal-lenging time for principals during the first few months after the lockdown, when schools were closed, since the principals had to make decisions with limited information from the National Department of Basic Education. The challenge will be for principals in areas where the parents and the learners do not have quality access to the Internet. Therefore, communication was difficult and to keep parents informed about what the learners needed to do, was a significant challenge. Financial challenges were strongly linked to the digital challenges for principals, while the safety of learners as well as poverty and meals which were not provided every day for learners, became basic needs and challenges. It has been indicated that no preparation or train-ing and development which principals received before the pandemic could have prepared them for this new challenge under unique circumstances. Once the schools opened again, they also had to follow alter-native timetables, since they could not accommodate all learners simultaneously, as stipulated by the social distancing for schools. The implication was that learners might have come to school only every second day or de-pending on the different timetabling even once a week or alternating dated weeks. This was stressful for principals who had to manage these processes, and teachers who have had to adapt their teaching methodologies, and time they had available, as well as for the learners who were not at school every day, and parents to support the learners at home. Many parents have also not been at home or were not qualified or felt able to support their children with their schoolwork.

\section{Jenna Wade and Raj Mestry share 'The Perceptions and Experiences of} School Management Teams and Teachers regarding Continuing Professional Development of Teachers in Digital Literacy amidst the COVID-19 Pandemic. The closure of schools since March 2020 exposed the lack of skills and training as well as facilities for most teachers in most schools in South Africa. The teachers therefore needed training in digital skills but since most schools do not have the necessary facilities, it was difficult for school management teams to continue the training of teachers with regard to the requirements and implementation of digital technology for the teaching during especially the closure of schools. Wade and Mestry 
emphasise that it is not only the lack of facilities and equipment but also the morale and dedication of teachers which presented as stumbling blocks for the training of teachers to equip them for the new challenges of teaching with learners who are not at school for long times. The research was conducted in primary schools and it was established that even the school management teams lack the knowledge and skills to train the teachers for what was needed in this new context. Since the training for digital technology were not conducted before the COVID-19 situation, it was nearly impossible to train the teachers during the initial lockdown time since teachers could not come to school or meet, and with the teachers and schools lacking technology, it was difficult, to impossible, to train the teachers to begin and to continue teaching with digital technology. This is a challenge over and above the situation which has been explained by different other authors in this edition - that the learners and their parents lack the facilities and internet infrastructure to receive further training. Thus, it is becoming a doubleedged, with teachers not being able to teach with technology, and learners who do not have the required facilities and internet access, which emphasise the challenges and inability for a large number of learners to continue their learning during lockdown, and even after the initial three month lockdown during time when all learners are not at school.

Felicia Williams and Juliet Perumal, focus on 'Female Principals' Narratives of Leading Schools in the Time of the COVID-19 Pandemic. The female leaders in schools work under the same circumstances as their male counterparts namely the challenges with regard to living on low socioeconomic contexts, and all the social ills which are associated with this situation. The authors argue that the dichotomy with regard to hierarchy between man/ woman, mind/ body, culture/ nature, reason/ emotion, public/ private, and objective/ subjective, must be addressed to ensure misperceptions or distorted perceptions about the abilities and performance of educational leaders with regard specifically to gender. The emotions and the affective became evident when the school leaders expressed the fear and anxiety about the challenges they faced, and also how to deal with their own, as well as those of teachers as well as learners and community. Although this is not a feeling which were only expressed by female leaders they were able to express themselves and share their emotional experiences, which indicated the significant influence it had on female leaders also as human beings. 
Together with all other leaders, they were challenged to lead, and have to be strong in some decisions, but also show humanity and empathy towards their followers. Along with the normal aggression and subversion which female leaders experience, the COVID-19 context created more challenges. The uncertainty of the leaders based on their own limited information and the allround insecurity and uncertainty, made these leaders even more vulnerable with regard to subversion from the staff. It is expected that leaders must lead and be strong and some of the female leaders found it difficult with the additional challenges related to the virus situation. In spite of the challenges parents experience in the situation, the leaders express their appreciation for the efforts of parents to assist and support their children. Although they were not always capable of supporting them, they still attempted to provide educative direction to the children.

\section{Ntombozuko Duku, Percival Mzuyanda Mavuso and Moses Sipho} Mkhomi, expand on the issues mentioned by Du Plessis, on the challenges for school leaders, in their article, 'The Experiences of Members of the School Governing Bodies in Executing their Duties during the COVID19 Pandemic Lockdown'. They place the emphasis on the role of the school governing body, and on information and communication technology which poses different but similar challenges than for the principals as leaders in the broader context of the school. A large number of governing bodies with the parents as the majority in the governing body, could not function effectively since the parents did not have the necessary skills or knowledge or technology to have electronic meetings. It was therefore difficult to make decisions which could include the governing body and specifically the parental component of the governing body. Although a large number of parents have cell phones they did not have sufficient data or money for data or the phones were not equipped with the required technology to enable meetings and discussions. Many of the governing body members are also elderly citizens, and therefore have not been part of the electronic explosion of the last decade, and were only able to communicate with one-on-one voice calls, or the SMS system. The request from the governing bodies were that the government must provide them with the necessary tools, the appropriate cell phones, and data and airtime, and even laptops, so that they can meet and communicate in larger groups. These meetings and communication are important since decisions need to be made together with the school leaderships, for example 
about funding, or the opening and closing of schools, and learning times, which are part of the responsibilities of the governing bodies.

The next article focusses on the initial phase in the education system and how this virus situation influenced the early childhood part of the system. Keshni Bipath and Adebunmi Aina emphasise the important role of context in their article, 'Early Childhood Development (ECD) Centre Leadership during COVID-19 in Urban and Rural Areas in South Africa'. The important challenge in this section of the education system was that after the closure of the early childhood development centres, they could not collect the needed operational fees which has a significant impact on the ability to open the schools, after schools were allowed to open again. This led to the closure of many centres, and unemployment in this sector were significant. In addition, at the beginning of the pandemic, the early childhood develop-ment section of the system was in a transfer process from the Department of Social Development to the Department of Basic Education, which created further disturbances in the kind and format of support they received from the government. The differences between the rural and urban contexts of these centres, were also a major aspect which influenced the leadership, and how they were able to lead in the new challenging circumstances of the pandemic. The principals in the urban areas were able to communicate effectively with most of the parents during the closure of the schools, and most of the learners returned to the schools. The rural areas had significant challenges, with communication being hampered by the socio-economic contexts of the parents, and the communities, and where, in some of the school, when the learners were allowed to return, a very few learners returned once schools opened.

Farhana Amod Kajee explores 'Educational Leadership and Management during COVID-19: A Call for Criticality and the Legitimation of Social Theory Data and Theory'. She argues that leadership studies lack criticality and social theory which are enhanced by the challenges principals who had to function as leaders during the COVID-19 phenomenon. She indicates that if social theories and criticality were better included in leadership programs for education leadership, they might have provided the possibility that principals are better equipped to handle challenges which occur during crises such as the COVID-19 pandemic. She further argues that it will prevent the failure of leadership, since current leadership training is a technical 
and practice orientated approach, rather than more deeply, theoretical and critical issues, of what these leaders are suppose and expected to do. Although the technical and practical orientation may be to the advantage of school leaders during the normal context of everyday schooling, the COVID19 context emphasises the challenges and lack of ability for principals to be fully equipped as leaders for crises situations, and so to cope with abnormal crises situations. The lack of training was also emphasised and therefore the argument for better theoretical training and development may be an option for principals to be better prepared for unforeseen challenges. The exposure to social theory may also result in the sensitising of educational leaders about the social injustices and complex and diverse education system which exist in South Africa, and which they have to provide leadership, in general, but also in the time of the COVID-19 pandemic.

Although this special edition of Alternation only focuses on the first six months of the COVID-19 pandemic in South Africa, it is providing an important window of the reaction of principals not only in South Africa but also in an international context. The similarities between the South African reactions and reactions in Kenya and China indicate the generic leadership challenges and reactions from the school leaders with the emphasis on the principals. The challenges were significant and at the time of the writing of this introduction, looking back, there is evidence that principals were able to cope with most of the challenges at their schools, although the quality of education might not have continued as it was before the COVID-19 crisis. This is predominantly in the schools in the low socio-economic context where the challenge still exists, and it does not seem as if there will be substantial improvements in the near future - except if children are able to move back to schools. This will also be influenced by the continuation of the virus situation and the willingness and motivation of teachers, learners and parent communities to support the efforts to 'normalise' the education as soon as possible. The possibility of the new Lost Generation is imminent and this can only be resolved with special leadership during the crisis. A new perspective with new research may provide more insight into the experiences of principals with regard to the phases of the crisis from the initial phase which has been portrayed in this special edition and then how they lead and act over a two or three year period. 


\section{References}

Di Pietro, G., F. Biagi, P. Costa, Z. Karpiński \& J. Mazza 2020. The Likely Impact of COVID-19 on Education: Reflections Based on the Existing Literature and Recent International Datasets. Luxembourg: Publication Office of the European Union.

Economic Policy 2019. Economic Transformation, Inclusive Growth, and Competitiveness: Towards an Economic Strategy for South Africa. South Africa: National Treasury.

http://www.treasury.gov.za/comm_media/press/2019/Towards\%20an \%20Economic\%20Strategy\%20for\%20SA.pdf

Francisco, C.D. \& A.V. Nuqui 2020. Emergence of a Situational Leadership during COVID-19 Pandemic Called New Normal Leadership. International Journal of Academic Multi-disciplinary Research (IJAMR) 4,10: 15 - 19.

https://files.eric.ed.gov/fulltext/ED608560.pdf

Grant, C. 2017. The Contribution of Education to Economic Growth. K4D Helpdesk Report. Brighton, UK: Institute of Development Studies. https://assets.publishing.service.gov.uk/media/5b9b87f340f0b6789697 7bae/K4D HDR The Contribution of Education to Economic Gro wth_Final.pdf

Harris, A. \& M. Jones 2020. COVID-19: School Leadership in Disruptive Times. School Leadership \& Management 40:4, 243 - 247.

https://doi.org/10.1080/13632434.2020.1811479

Khlaif, Z.N., S. Salha, S. Fareed \& H. Rashed 2021. The Hidden Shadow of Coronavirus on Education in Developing Countries. Online Learning 25,1: 269 - 285.

https://doi.org/10.24059/olj.v25i1.2287

Kochańczyk, M. \& T. Lipniacki 2021. Pareto-based Evaluation of National Responses to COVID-19 Pandemic Shows that Saving Lives and Protecting Economy are Non-trade-off Objectives. Scientific Reports 11,1: 1 - 9 .

https://doi.org/10.1038/s41598-021-81869-2

PMid:33510274 PMCid:PMC7844048

Maital, S. \& E. Barzani 2020. The Global Economic Impact of COVID-19: A Summary of Research. Samuel Neaman Institute for National Policy Research. Available at: 
Phumlani E. Myende \& Jan Heystek

https://www.neaman.org.il/EN/Files/Global\%20Economic\%20Impact \%20of\%20COVID-19_20200322163553.399.pdf

(Accessed 10 September 2021).

McKibbin, W. \& R. Fernando 2020. The Global Macroeconomic Impacts of COVID-19: Seven Scenarios. Brookings Institute. 2 March 2020: 1 - 43. https://www.brookings.edu/wpcontent/uploads/2020/03/20200302_COVID19.pdf

Metcalfe, L.S. \& I. Perez 2020. Blinded by the Unknown: A School's Leader's Authentic Actions to Support Teachers and Students during COVID-19 School Closures. Journal of School Administration Research and Development 5,S1: 49 - 54.

https://doi.org/10.32674/jsard.v5iS1.2746

Mhlanga, D. \& T. Moloi 2020. COVID-19 and the Digital Transformation of Education: What are we Learning on 4IR in South Africa? Education Sciences 10,7: 10, 180.

https://doi.org/10.3390/educsci10070180

Myende, P.E. \& N. Ndlovu 2020. COVID-19 and Emergency Online Teaching and Learning: A Challenge of Social Justice for University Rural Students. In Smit, J.A, N. Mkhize, N. Ndimande-Hlongwa \& L. Ramrathan (eds.): Learner and Subject at the Dawn of Digital Research-Led Teaching and Learning in the Time of COVID-19.

Durban: CSSALL.

https://doi.org/10.29086/978-0-9869936-5-7/2020/AASBS04

Chapter URL pp. 167 - 187.

http://alternation.ukzn.ac.za/Files/books/series/04/07-myende.pdf

Park, S. 2017. Digital Inequalities in Rural Australia: A Double Jeopardy of Remoteness and Social Exclusion. Journal of Rural Studies 54: 399 407. https://doi.org/10.1016/j.jrurstud.2015.12.018

Poudel, K. \& P. Subedi 2020. Impact of COVID-19 Pandemic on Socioeconomic and Mental Health Aspects in Nepal. International Journal of Social Psychiatry 66,8: 748 - 755.

https://doi.org/10.1177/0020764020942247

PMid:32650687 PMCid:PMC7443960

Ramij, M. \& A. Sultana 2020. Preparedness of Online Classes in Developing Countries amid the COVID-19 Outbreak: A Perspective from Bangladesh. Afrin 29 June.

https://doi.org/10.2139/ssrn.3638718 
Tadesse, S. \& W. Muluye 2020. The Impact of the COVID-19 Pandemic on the Education System in Developing Countries: A Review. Open Journal of Social Sciences 8,10: 159 - 170.

https://doi.org/10.4236/jss.2020.810011

Viner, R.M., S.J. Russell, H. Croker, J. Packer, J. Ward, C. Stansfield, O. Mytton, C. Bonell \& R. Booy 2020. School Closure and Management Practices during Coronavirus Outbreaks including COVID-19: A Rapid Systematic Review. The Lancet Child \& Adolescent Health 4,5: 397 404. https://doi.org/10.1016/S2352-4642(20)30095-X

Associate Professor Phumlani E. Myende Educational Leadership, Management and Policy Academic Leader: Masters Studies School of Education Edgewood Campus University of KwaZulu-Natal Durban

MyendeP@ukzn.ac.za

Professor Jan Heystek Edu-Lead Research Faculty of Education North West University Potchefstroom jan.heystek@nwu.ac.za 